\title{
Growth and Reproduction of the Chinchilla-Age at Vaginal Opening, Oestrous Cycle, Gestation Period, Litter Size, Sex Ratio, and Diseases Frequently Encountered
}

\author{
Junichi KUROIWA and Tomonori IMAMICHI \\ Department of Physiology, Nippon Veterinary and Zootechnical \\ College, 1-7-1 Kyonan-cho, Musashino-shi, Tokyo, Japan
}

(Received for publication : November 30, 1976)

\begin{abstract}
The paper deals with observations on growth and reproduction of the chinchilla in recent 4 years started from 1966 at this laboratory. There were large variations in age of vaginal opening (less than 71 days-308 days) with an average of $173.2 \pm 57.6$ days in 45 females. The average length of 100 oestrus cycles in 24 females was $35.7 \pm 7.9$ (15-62) days. The mean period of 5 gestations in 5 females was 110.4 (108-112) days. Eighty-one out of 123 litters were born between March and August during 3 years, and parturition never occurs in December. The most suitable season for reproduction of chinchillas may be from January to April, and a summer anoestrous seems to be present in August to early September as reported by Weir. The litter size ranged from 1 to 4 with a mode of $2(46.3 \%)$ and an average of $1.90 \pm 0.76$. More male kids were produced at birth at this laboratory, and sex ratio was 133.7 (98 females and 131 males). In 1973,37 chinchillas gave birth to 71 kids with an average litter size of 1.92 , and 59 of them were successfully weaned (1.59 per litter). Of these kids, 50 (1.35 per litter) attained 240 days of age (adulthood). Among 91 subjected to investigation for causes of death, $23(25.3 \%)$ were dead during newborn period, and 9 and 5 adults were dead of malocclusion (9.9\%) and the prolapse of rectum respectively.
\end{abstract}

\section{チンチラの発育と繁殖一初回臸開口日令・性周期・ 妊娠期間・性比・飼育中頻発する疾病 \\ 黒岩純一・今道友則 \\ 日本獣医蓄産大学生理学教室}

チンチラ (Chinchilla laniger) (Fig. 1) は鳌歯目 (Rodentia), ヤマアラシ亜目 (Hystricomorpha), チ ンチラ科 (Chinchillidae), チンチラ属 (Chinchilla) の動物で, モルモット (Cavia porcellus) やヌートリ 了 (Myocaster coypus) と比較的近縁である。チンチ ラの毛は極めて細く 1 コの毛包から 80 100 本の極めて
細い毛が生えており $[8]$, その毛皮は非常にやわらかく， 世界で最も高級の毛皮とされている。原産地は多くのヤ マアラシ亜目の動物と同じく南米で, Peru, Bolivia, Chile, Argentina の Andes 山脈の 4,500m 以上の山 岳地に棲息している。しかし高価な毛皮のため大規模に 狩併が行われ, 乱獲の結果褄息数が著しく減少し, 今日 
では野生のチンチラはほとんど存在していないと言われ る。かつては数種のものがあったらしいが，Weir によ るとC. laniger とC. brevicaudata の 2 種だけが現 在認められている[12, 13]。後者は前者よりやや大きく, 耳と尾が短かく，妊娠期間が長い。産業上繁殖されてい るのは前者だけである。以下の文中チンチラとは C.laniger を指すことにする。

チンチラの飼育繁殖は1923年米国の鉱山技師Mathias

F. Capman 氏によって始められた $[8]$ 。彼は当時チン チラの捕獲が禁止されていたので，ペル一政府の許可を 得て南米からカリフォルニアへ12匹（雌 4 , 雄 8 ) の于 ンチラを持ち帰り，高地棲息動物を低地で飼育するため に苦心を重ねて繁殖に成功した。このチンチラが今日世 界で繁殖されているチンチラの主な祖先である。

わが国においては1961年静岡県三島市の愛好家によっ て導入されたのが最初のものと考兄られている[6]。当 研究室では 1966年 Los Angels の黒住一井女史により 寄贈ならびに指導を受けてチンチラの飼育繁殖が開始さ れ，その後1972年に八王子市の粕谷次男氏からも雌46, 雄44匹の寄贈を受け, 以来常時120１50匹を飼育し，実 験動物化および毛皮産業の発展を目標として研究を行な っている。

本報は当研究室において最近 4 年間に得られたチンチ ラの発育, 繁殖に関する成績のらち, 初回腔開口日令, 性周期, 妊娠期間, 月別分姢数, 産仔数, 性比, 繁殖育 成成績および飼育中頻発する疾病などの成績をまとめた ものである。

\section{材料および方法}

飼育には通常のチンチラ産業用の polygamous breeding cage (Fig. 2) を用い, 夏季には通風（1974 年 まで）あるいはクーラー（1975 年以降），冬季には石油 ストーブによる軽い暖房下 $\left(7 \sim 25^{\circ} \mathrm{C}\right)$ で飼育した。 照明は自然光により, 照明時間の調節を行わなかった。 飼料には船橋農場製のチンチラ用固型用飼料を用いた。 この飼料は今道が黒住女史の依頼を受け, 東洋諸国のチ ンチラ用固型飼料をわが国で生産することを計画し，船 橋農場の渡来氏と相談して製作したものである。その組 成は Table 1 のごとくである。床敷には米国では White-pine 材のチップを使用しているが入手できないの でモミ材と外材の混じったチップを使用した。また毛皮 の湿気を取り除くためチンチラに砂浴びを 1 時間程度さ せた。砂には Blue Cloud (Blue Cloud Mineral
Table 1. Chemical composition of pelet feeds for chinchilla (Funabashi Farm)

\begin{tabular}{lc}
\hline Water & $6.0 \%$ \\
Crude Protein & 18.0 \\
Crude Fat & 3.2 \\
Crude Fiber & 10.8 \\
Crude Ash & 7.0 \\
Nitrogen Free Extract & 55.0 \\
\hline
\end{tabular}

Company P. O. BOX 125 Newhall, California) を 用いこれを砂風呂（sand bath）に入れケージ内に入れ て砂浴びをさせた。なお西ドイッでは大理石の粉末を使 用している。繁殖は一夫多妻式 (polygamous breeding）で行なった。すなわち通常の 3 連のチンチラ飼育 ケージを合わせて 6 連にし, 一番左に雄動物を置き, 他 に雌動物を $3 〜 5$ 匹（普通 3 匹）を置いた。雄は通路を 通って雌のケージに自由に出入できるが，雌には出入口 を通って通路に出れないように金属製あるいはプラスチ ック製の首輪をしておいた（Fig. 3)。離乳はWeir に よると 6 〜 週令で行ならが，60日令で行なわれる場合 もあり [5], 当研究室では安全のため原則として60日令 で行なった。

\section{成績および考察}

\section{1. 初回胵開口日令}

Table 2 にチンチラの初回胵開口日令を示した。使 用した動物は1973年および1975年に生まれた雌チンチラ である。出生後胵が初めて開き出し, 全開時の横径のほ ぼ半分の長さである $2.5 \mathrm{~mm}$ 以上開いた場合を胵開口と 認めた。45匹の初回胵開口日令の平均は $173.2 \pm 57.6$ 日 であった。最も腔開口の早い動物 (C-4) では71 日令 ですでに胵が開いていた。これを含め 45 匹中 7 匹（C4, A-70, A-48, C-8, C-2, C-75, A-32) では 腟開口日令が非常に早かったために開口日を確認できな かったものがあった。この場合には発見日をもって腔開 口日令として算出した。腔開口日令が最も遅い動物では 308 日令（10ケ月）で腔開口しており，胵開口日令には 変異が大きいことが認められた。Weir は初回腟開口日 令は出生季節によって異なり, その年遅く生まれたチン チラは次回の繁殖季節（11月～5月）まで胵が開口しな いと報告している [12]。そこで著者らは 45 匹について 生れた時季と腔の初開口の時季との関係を調査した。腔 

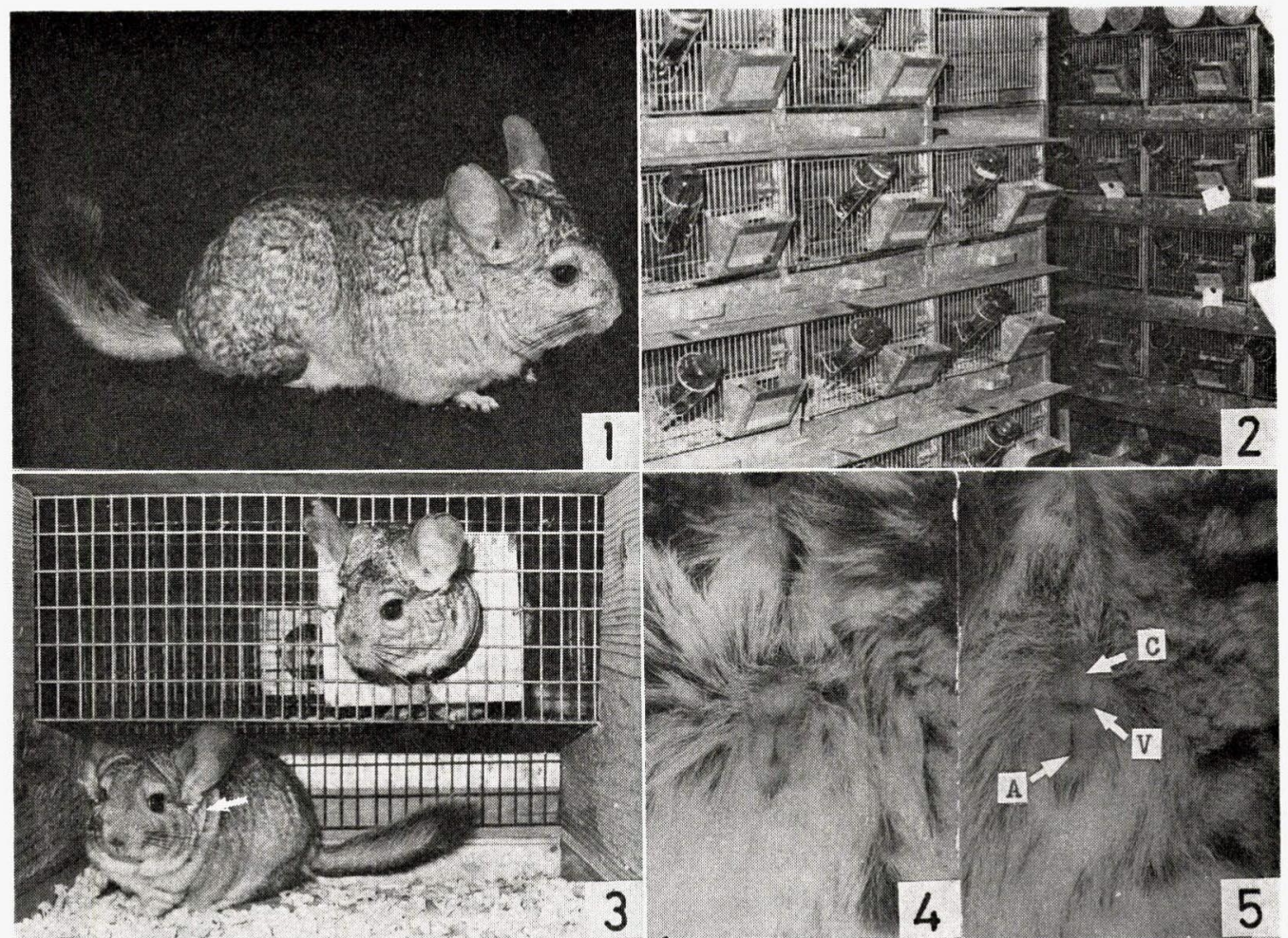

\section{우 $\mathrm{A}-54$ (3年令)}


우 $\mathrm{B}-15$ (2年令)

\section{$+9-54$ (3年令)}
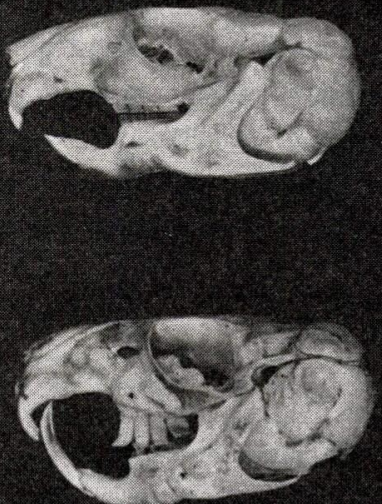

+ $\mathrm{B}-15$ ( 2 年令) 
Table 2. Age at first vaginal opening of the chinchilla

\begin{tabular}{cc||cc}
\hline Animal No. & $\begin{array}{c}\text { Age at Vaginal } \\
\text { Opening (days) }\end{array}$ & Animal No. & $\begin{array}{c}\text { Age at Vaginal } \\
\text { Opening (days) }\end{array}$ \\
\hline C -4 & $<71$ & $\mathrm{C}-11$ & 172 \\
$\mathrm{~A}-70$ & $73-74$ & $\mathrm{C}-27$ & 176 \\
$\mathrm{C}-17$ & 88 & $\mathrm{C}-16$ & 181 \\
$\mathrm{~A}-48$ & $85-91$ & $\mathrm{C}-57$ & 182 \\
$\mathrm{C}-8$ & $93-99$ & $\mathrm{C}-72$ & 189 \\
$\mathrm{C}-2$ & $<105$ & $\mathrm{C}-15$ & 198 \\
$\mathrm{C}-10$ & 108 & $\mathrm{~A}-42$ & 198 \\
$\mathrm{C}-75$ & $<111$ & $\mathrm{~A}-71$ & 202 \\
$\mathrm{~A}-32$ & $113-119$ & $\mathrm{C}-55$ & 209 \\
$\mathrm{C}-80$ & 117 & $\mathrm{~A}-53$ & 211 \\
$\mathrm{~A}-54$ & 123 & $\mathrm{C}-37$ & 216 \\
$\mathrm{~A}-47$ & 133 & $\mathrm{~A}-21$ & 229 \\
$\mathrm{C}-73$ & 132 & $\mathrm{C}-53$ & 230 \\
$\mathrm{~A}-59$ & 137 & $\mathrm{~A}-57$ & 232 \\
$\mathrm{C}-3$ & 140 & $\mathrm{C}-63$ & 239 \\
$\mathrm{~A}-67$ & 145 & $\mathrm{~A}-33$ & 241 \\
$\mathrm{C}-32$ & 149 & $\mathrm{C}-65$ & 242 \\
C -38 & 149 & $\mathrm{~A}-15$ & 251 \\
$\mathrm{C}-28$ & 155 & $\mathrm{~A}-58$ & 253 \\
$\mathrm{C}-19$ & 156 & $\mathrm{~A}-10$ & 257 \\
$\mathrm{~A}-31$ & 162 & $\mathrm{~A}-56$ & 281 \\
$\mathrm{~A}-51$ & 165 & $\mathrm{~A}-36$ & 308 \\
$\mathrm{C}-36$ & 167 & & \\
\hline
\end{tabular}

Mean : $173.2 \pm 57.6(<71-308)$ days .....45 Femals

の初開口日令は，繁殖季節（11月〜 5 月）に生れたもの 13匹では平均 $170.0 \pm 73.7$ 日で, 繁殖季節を過ぎて 6 〜 10月に生れた動物32匹でも平均 $174.5 \pm 49.6$ 日でありい ずれも約 6 ケ月で殆んど差がなかった。しかも繁殖季節 に生れたものは繁殖季節外に腟が開口し，繁殖季節を過 ぎて生れたものは次回の繁殖季節に胵が開口するといら 傾向が当然みられることになり，Weir のいらところは 必ずしも当を得てない。

\section{2. 性周期}

Stockard \& Papanicolau [9]がモルモットの性周 期を胵坧像の変化で判定する方法を確立して以来各種の 漓歯類の性周期は胵坧像で判定されるようになった。著 者らもチンチラの腔恬像を調べているが, Bullard [1] のいらようには明膫に判定できない点は遠藤 [3] と同 様であり，目下検討中である。一方胵口の開閉が明瞭で あるので (Fig. 4, 5), 以下には腔口の開閉による判定
法で性周期を調べた。Fig. 6. とは初回腔開口直後より の腔口開閉を連日調查して判定した性周期を示した。使

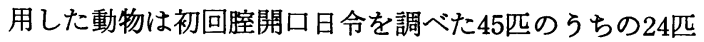
である。6 割以上の動物では全開時の腔口の巾（横径） は $5 \mathrm{~mm}$ 以上であるので, 腔が全開時のほぼ半分の巾で ある2.5mm以上開いている場合を腔が開いているとし， それ以外を腔が閉じているとし，胵が開いている日と閉 じている日の合計を性周期とした。24匹 100 周期の平均 は35.7士7.9日であり，15 62 日の範囲であった。一般 に腔口は急に全開して後, 徐々に閉じていくょうな経過 をとるが，腟が開いている日数は $10.4 \pm 5.7$ 日であり， 1〜33 日の範囲であり，腔が閉じている日数は $25.2 \pm$ 7.8日で 10 54 日の範囲であった。な初回腔開口後の 最初の性周期が異常に長く䐋の開口状態が長く続いた 1 匹（A-71），腟の開閉が不明確であった 2 匹（C-28， C-72), 2 回目の周期が甚だしく不明瞭で明確な胵閉鎖 が長期間みられなかった 1 匹（C-17）および 初回膑開 
Table 3. Days of gestation period of the chinchilla

\begin{tabular}{crcccc}
\hline Animal No. & $\begin{array}{l}\text { Date of } \\
\text { copulatin }\end{array}$ & $\begin{array}{l}\text { V. Plug } \\
\text { confirmed }\end{array}$ & $\begin{array}{l}\text { Sperm } \\
\text { confirmed }\end{array}$ & $\begin{array}{l}\text { Date of } \\
\text { perturition }\end{array}$ & $\begin{array}{l}\text { Gestation } \\
\text { period }\end{array}$ \\
\hline K I & 73.12 .24 & - & + & 74.4 .15 & 112 \\
A - 15 & 74.1 .11 & + & + & 5.1 & 110 \\
72 F 1 & 3.31 & + & + & 7.17 & 108 \\
T - 22 & 4.5 & - & + & 7.26 & 112 \\
A - 10 & 6.15 & - & + & 10.3 & 110 \\
\hline
\end{tabular}

Mean : 110.4

\begin{tabular}{|c|c|c|}
\hline $\begin{array}{c}\text { Animal } \\
\text { No. }\end{array}$ & $\begin{array}{l}\text { Age at } 1 \text { st } \\
\text { Vaginal Opening }\end{array}$ & First Vaginal Openings \\
\hline A - 36 & 308 days & 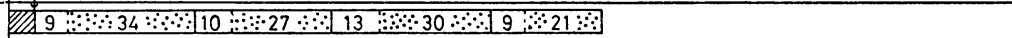 \\
\hline A- 56 & 281 & 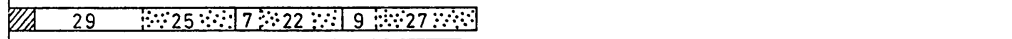 \\
\hline$A-57$ & 232 &  \\
\hline A -58 & 253 & 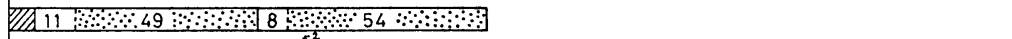 \\
\hline A -70 & 216 & 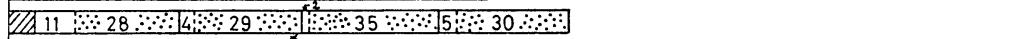 \\
\hline A- 71 & 202 & $219: 17: 6: 27: 03$ \\
\hline$c-11$ & 172 & 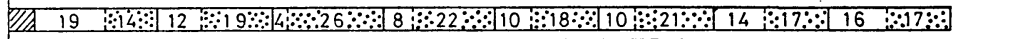 \\
\hline$c-15$ & 198 &  \\
\hline$c-16$ & 181 & 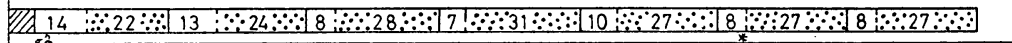 \\
\hline$c-17$ & 88 & $4: 29: \div \quad 11 \quad \therefore 27 \div \because 113$ \\
\hline$c-19$ & 156 & 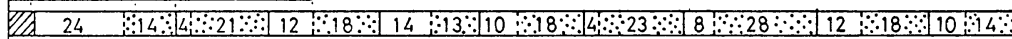 \\
\hline$c-27$ & 176 &  \\
\hline$c-28$ & 155 & 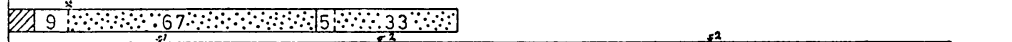 \\
\hline$c-32$ & 149 & 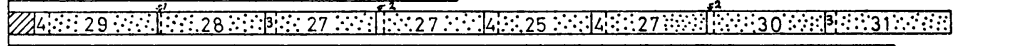 \\
\hline$c-36$ & 167 & 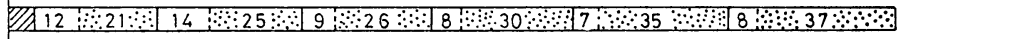 \\
\hline$c-37$ & 216 & $2415: 12: 9: \because 23 \div 13: 16: 18: 23 \div 111: 22 \div 14: 23: 0$ \\
\hline$c-38$ & 149 & 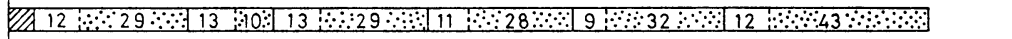 \\
\hline$c-53$ & 230 & $2010: 65.35$ \\
\hline$c-55$ & 209 &  \\
\hline$c-57$ & $\begin{array}{l}182 \\
239\end{array}$ & 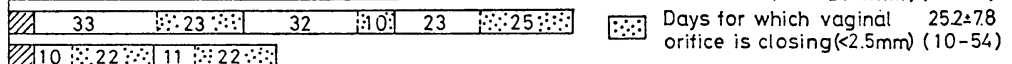 \\
\hline $\begin{array}{c}c-63 \\
c-65\end{array}$ & 242 & Oestrous cycle $35.7: 7.9(15-62)$ \\
\hline$c-72$ & 189 & 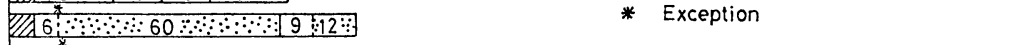 \\
\hline$c-75$ & $<111$ & $287: 17: 18: 23 \because 16: 23: 10 \div 22: 18: 20: 19: 22 \%$ \\
\hline
\end{tabular}

Fig. 6. Oestrous cycles of the che chinchilla (after first vaginal openings)

[100 oestrous cycles in 24 females]

口日をつかみそこねたために初回周期日数を確認できな かった 1 匹（C-75）の計 5 匹の延べ 5 周期（図中 $*$ 印） については集計から除外した。同一個体で 3 回以上の周 期を調べたもの16匹中で各個体の周期の長さの変動を調 べると，個体内差異が 7 日以内で周期日数が比較的そろ っているもの 7 匹，15日以内の差のもの 6 匹，25〜32日 の差のもの 3 匹であった。このように個体内の性周期日 数の変動の少いものがみられることから推測して, 育種
によって性周期を斉一化させる可能性があるように思わ れる。

\section{3. 妊娠期間}

5 匹の繁殖倠について腔垢中の精子の存在によって交 尾の成立を確認して分婏まで観察した 5 妊娠期間の平均 は110.4日で 108-112 日の範囲であった(Table 3)。ヤマ アラシ亜目の動物は体の大きさの割に妊娠期間が長いこ 
とが知られている。ヤマアラシ亜目の動物では最も妊娠 期間が短いものでも Galea musteloides クイ (Cuis) の52日であり, 一方最も妊娠期間が長いのはErethizon カナダヤマアラシ North American branickii パカ ラナ（Pacarana）の222～283日であるという [14]。

\section{4. 月別分娭数}

Table 4 に 1973 年 1975 年の月別分婏数を示した。 1973年の 1 月〜 3 月は分娩数 0 であった。ただし，粗谷 園からほとんど交配されていない雌46匹を1972年11月〜 12月に 3 回に分けて導入し直ちに雄と同居させた関係か

Table 4. Litters delivered in evry month

\begin{tabular}{l|rrr|r}
\hline Year & 1973 & 1974 & 1975 & Total (\%) \\
\cline { 1 - 5 } Month & 0 & 0 & 2 & $2(1.6)$ \\
Feb. & 0 & 1 & 1 & $2(1.6)$ \\
Mar. & 0 & 2 & 0 & $2(1.6)$ \\
Apr. & 2 & 1 & 3 & $6(4.9)$ \\
May & 12 & 6 & 1 & $19(15.5)$ \\
June & 7 & 3 & 14 & $24(19.5)$ \\
July & 1 & 10 & 7 & $18(14.6)$ \\
Aug. & 8 & 6 & 6 & $20(16.3)$ \\
Sept. & 3 & 4 & 4 & $11(8.9)$ \\
Oct. & 3 & 1 & 4 & $8(6.5)$ \\
Nov. & 1 & 5 & 5 & $11(8.9)$ \\
Dec. & 0 & 0 & 0 & $0(0)$ \\
\hline Total & 37 & 39 & 47 & $123(99.9)$ \\
\hline
\end{tabular}

ら約 4 ケ月の妊娠期間を考虑すれば1973年. 3 月以降に生 れ始めるはずであるので, 1 月〜 2 月の間に生れていな いのは人為的な影響によるものと一応考えられる。しか し常時同居を続けていた条件下の1974年, 1975年の 1 月 〜 3 月でも分娩数が少ないことからみて，この時期には チンチラの出生は非常に少いものと考えてよかろら。こ のよらな関係で一般に 1 月〜 3 月の分娩数は非常に少な いと考えられるので1973年の人為的条件がなかったとし てもこの 3 ケ月間に 1 腹程度づつ分娩するにすぎず大勢 に影響がないと考えて1973年の成績を含めた 3 年間の分 娩数を合計した月別分婏数の割合を算出し， Fig. 7 に 図示した。4月〜11月の分娩数は 117 腹で全体の $95.1 \%$ を占めている。特に 5 月〜 8 月の分娩数が多く各月 20 腹 内外で, この 4 ケ月の間に 81 腹 $65.9 \%$ が分娩している。 従って妊娠期間約 110 日（約 4 ケ月）をさかのぼると 4 月〜 11 月分婏のものは12月～ 7 月に交尾したことになり，

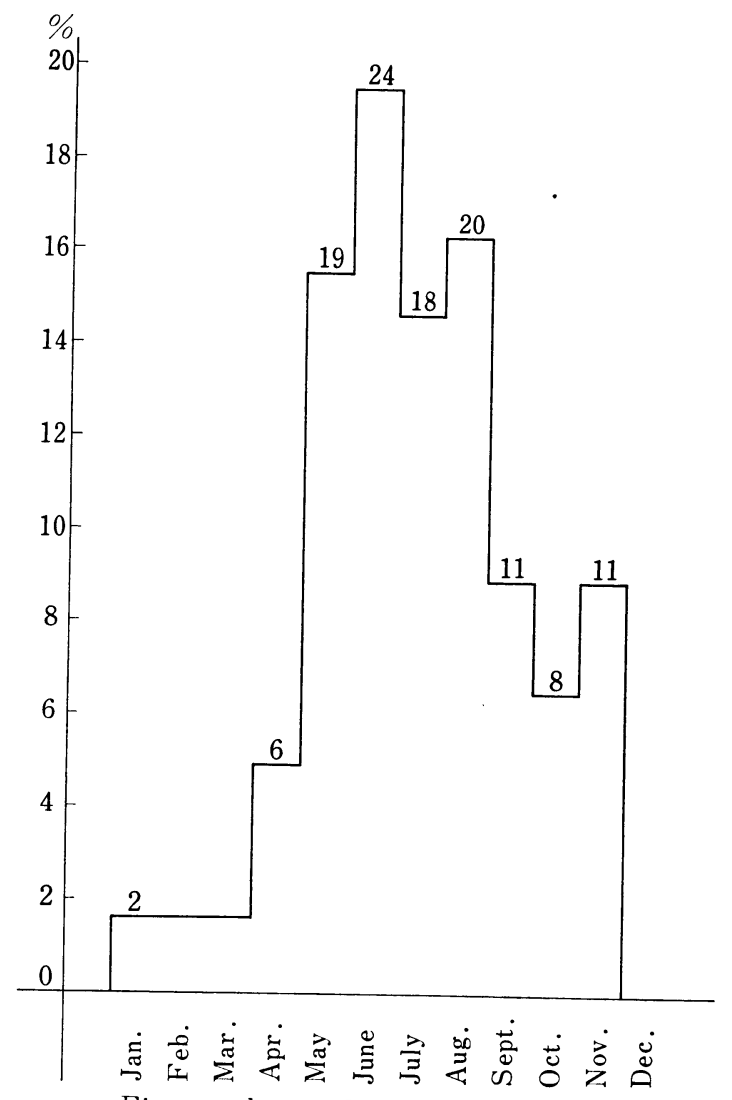

Figures above column mean litters

Fig. 7. Monthly rate of deliveries in 3 years (1973-1975)

5 月〜8 月に分婏したものが交尾した 1 月〜 4 月寸なわ ち春がチンチラの繁殖に最も適した季節と考えられる。 12月にはどの年も分娩が見られず，妊娠期間をさかのぼ ると 8 月には受胎しないよらであり, Weir のいう summer anoestrous と考えられる $[11,12,13]$ 。なお, 前述のように性周期が長く不斉一のため発情した動物を 選んで数をそろえることが難しいので毎月の交配数をそ ろえることができなかった。

\section{5. 産仔数}

Table 5 に 1973年〜1975 年に分娩したチンチラの産 仔数を示した。1973年の成績では，1腹 1 匹のものが 11 腹で $29.7 \%, 1$ 䧗 2 匹のものが 18 腹で $48.6 \%, 1$ 腹 3 匹 のものが 8 腹で $21.6 \%$ であった。平均産仔数は $1.92 \pm$ 0.72匹であった。1974年, 1975年には 1 腹 4 匹のものが 1 腹づつあった。 3 年間の合計では 1 腹 1 匹のものが 40 腹で $32.5 \%, 1$ 腹 2 匹が最も多く57腹 $46.3 \%, 1$ 腹 3 匹 
Table 5. Litter size of the chinchilla in every 3 year

\begin{tabular}{ccccc}
\hline \multirow{2}{*}{ Litter Size } & \multicolumn{5}{c}{ No. of Litters (\%) } \\
\cline { 2 - 4 } & 1973 & 1974 & 1975 & Total \\
\hline 1 & $11(29.7)$ & $13(33.3)$ & $16(34.0)$ & $40(32.5)$ \\
2 & $18(48.6)$ & $16(41.0)$ & $23(48.9)$ & $57(46.3)$ \\
3 & $8(21.6)$ & $9(23.1)$ & $7(14.9)$ & $24(19.5)$ \\
4 & $37(99.9 \%)$ & $39(100.0 \%)$ & $47(99.9 \%)$ & $123(99.9 \%)$ \\
\hline Total & $1.92 \pm 0.72$ & $1.95 \pm 0.81$ & $1.85 \pm 0.74$ & $1.90 \pm 0.76$ \\
\hline $\begin{array}{c}\text { Average } \\
\text { Litter Size }\end{array}$ & & $1(2.6)$ & $1(2.1)$ & $2(1.6)$ \\
\hline
\end{tabular}

のものが 24 腹で $19.5 \%, 1$ 腹 4 匹が最高産仔数で 2 腹で $1.6 \%$ あ゙あり, 平均産仔数は $1.90 \pm 0.76$ 匹であった。今 後産仔数の多い方へ育種していく必要があろら。

6. 性 比

Table 6 に 1973年〜1975 年の産仔数（死産を含む） と性比を示した。 3 年間の合計では産仔数雌 98 匹, 雄 131匹，性別不明 5 匹，計234匹であった。このらち性別 不明の 5 匹を除いた229匹の動物の性比は133.7と高く, 他の動物に比較し雄が多いよ5である。Galton [4]の 成績でも 10,664匹の生きて生まれた動物の性比は119.15 で雄が多いことが報告されており，彼等はこの原因をX 染色体と $\mathrm{Y}$ 染色体の大きさが甚しく違っていることと関 連があるかもしれないと言っている。チンチラの染色体 はモルモットと同じで 2n=64であり [7], X染色体に 比べてY染色体が相当小さい。
Table 6. Newborn chinchillas and sex ratio in every year

\begin{tabular}{ccccc}
\hline Year & $\begin{array}{c}\text { No. of } \\
\text { Newborn }\end{array}$ & Female & Male & Unknown \\
\hline 1973 & $71(66)$ & $27(26)$ & $41(40)$ & $3(0)$ \\
1974 & $76(75)$ & $37(37)$ & $39(38)$ & 0 \\
1975 & $87(83)$ & $34(33)$ & $51(50)$ & $2(0)$ \\
\hline Total & $234(224)$ & $98(96)$ & $131(128)$ & $5(0)$
\end{tabular}

Sex Ratio : 133.7 (229 heads)

No. in parenthesis means live births.

Unknown : External genitalia of some stillbirths was bitten off.

\section{7. 繁殖育成成績}

1973年には増殖を目的として，出生動物を育成中他の

Table 7. Results of reproduction and raising of chinchillas in 1973

\begin{tabular}{|c|c|c|c|c|c|c|c|c|c|c|}
\hline & \multirow{2}{*}{$\begin{array}{l}\text { No. of } \\
\text { Delivery }\end{array}$} & \multicolumn{3}{|c|}{ No. of Newborn } & \multirow[b]{2}{*}{ Total } & \multirow[t]{2}{*}{ Sucklings } & \multirow{2}{*}{$\begin{array}{l}\text { Weanlings } \\
60 \text { Days }\end{array}$} & \multicolumn{3}{|c|}{ s Living Animals } \\
\hline & & 오 & $\hat{o}$ & Unknown & & & & 90 & 120 & 240 \\
\hline Apr. & 2 & 2 & 2 & 1 & 5 & 4 & 4 & 2 & 1 & 1 \\
\hline May & 12 & 6 & 18 & 2 & 26 & 24 & 22 & 21 & 20 & 20 \\
\hline June & 7 & 7 & 6 & & 13 & 13 & 12 & 8 & 8 & 8 \\
\hline July & 1 & 1 & 1 & & 2 & 2 & 2 & 2 & 2 & 2 \\
\hline Aug. & $8(7)$ & $7(6)$ & $8(7)$ & & 15 & 13 & 10 & 10 & 10 & 10 \\
\hline Sep. & 3 & 1 & 4 & & 5 & 5 & 5 & 5 & 5 & 5 \\
\hline Oct. & 3 & 3 & 1 & & 4 & 4 & 3 & 3 & 3 & 3 \\
\hline \multirow[t]{3}{*}{ Nov. } & 1 & 0 & 1 & & 1 & 1 & 1 & 1 & 1 & 1 \\
\hline & $37(36)$ & $27(26)$ & $41(40)$ & 3 & 71 & 66 & 59 & 52 & 50 & 50 \\
\hline & & \multicolumn{3}{|c|}{ Kids per Litter } & 1.92 & 1.78 & 1.59 & 1.41 & 1.35 & 1.35 \\
\hline
\end{tabular}


実験に使用せずに育てたので，1973年の繁殖育成成績を Table 7 に示した。 4 月には分婏数 2 腹, 産仔数は雌 2 匹，雄 2 匹，死産のため性別不明 1 匹で, 計 5 匹であ った。哺育仔数，離乳仔数はともに 4 匹，90日令での生 存数は 2 匹，120日令での生存数は 1 匹，240日令での生 存数は 1 匹であった。 5 月には分婏数が 12 腹で, 産仔数 は雌 6 匹, 雄18匹, 死産で性別不明 2 匹で, 計26匹であ った。哺育仔数は $24 匹$, 離乳仔数は $22 匹$, 生存数は 90 日 令で 21匹，120日令および成熟に達したものは 20匹であ った。この様にして 1 年間の合計では，分婏数は 37 腹， 死産 1 を除くと36腹, 産仔数雌 27 匹，死産を除くと $26 匹 ，$ 雄41匹，死産を除くと40匹，死産のため性別不明 3 匹， 総計71匹で 1 腹当り平均産仔数は 1.92 匹であった。哺育 仔数は66匹， 1 腹平均 1.78 匹，離乳仔数は 59 匹， 1 腹平 均1.59匹であった。その後の生存数は90日令で52匹，1 腹当り1.41匹，120日令で50匹，1腹当り1.35匹，240日 令つまり成熟に達するとみなされる日令に達したもの50 匹で 1 腹当り1.35匹であった。1974年，1975年の経験で この成績より育成率を多少向上させる可能性はあるけれ ぞも, チンチラの増殖率は極めて低いといえる。

\section{8. 飼育中頻発する疾病}

1971年 4 月〜1976年 9 月の 5 年 6 ケ月間に死亡した于 ンチラは 145 匹あった。この内 54 匹にいては著者のひ とり黒岩が健康を害していた時期で死因を調査していな い。この54匹を除いた 91 匹の動物の死因の例数と割合を Table 8 に示した。

咬傷および夏期の熱射病等事故死が 26 匹 (28.6\%), 乳仔の死亡が䧳 9 匹，雄14匹，計23匹（25.3\%）と最も 多い。乳仔の死亡では $0 \sim 3$ 日令に死亡のもの 12 匹，4 ～15日令に死亡のもの 7 匹，16〜30日令に死亡のもの 4 匹であり，すべて哺育期前半に死亡しており，後半期す なわち31〜60日令に死亡のものは見られなかった。死亡 した乳仔の 0 日令の体重は雌 $33.1 \pm 6.9 \mathrm{~g}$, 雄 $34.5 \pm 7.3$ $\mathrm{g}$ であり, 正常な初生仔体重の平均（雌42.9 $\pm 6.9 \mathrm{~g}$, 雄 $41.1 \pm 6.7 \mathrm{~g}$ ）より軽かった。

次に不正咬合が 9 匹 $(9.9 \%)$ ，直腸脱が 5 匹 $(5.5 \%)$ と多いのが特徵的であったので, Table 9 に不正咬合, 直腸脱で死亡したチンチラの年令，体重を示した。直腸 脱は年令に関係なく発生しているが，不正咬合は通常 2 年あるいはそれ以上経てから障害が現われる。不正咬合 になった動物では飼料の摄取がうまくいかなくなり，や せて衰弱死する。その臨床症状はやせてくることと，多 くの例では唾液で毛がぬれてよごれてくることなどであ
Table 8. Causes of death of chinchillas in 6 years (Apr. 1971 - Sept. 1976)

\begin{tabular}{lrc}
\hline \multicolumn{1}{c}{ Causes of death } & Number & $\%$ \\
\hline Babies Death & 23 & 25.3 \\
Malocclusion & 9 & 9.9 \\
Rrolapse of Rectum & 5 & 5.5 \\
Pneumonia & 4 & 4.4 \\
Gastrointestinal Haemorrhage & 3 & 3.3 \\
Hyper Swelling of Spleen & 2 & 2.2 \\
Death of Pregnant Mother & 2 & 2.2 \\
Retained after Birth & 1 & 1.1 \\
Accidental Death & 26 & 28.6 \\
Bitten & 9 & 9.9 \\
Heat Prostration & 8 & 8.8 \\
Broken Bones & 1 & 1.1 \\
Others & 8 & 8.8 \\
Unknown & 16 & 17.6 \\
\hline \multicolumn{1}{c}{ Total } & 91 & 100.0 \\
\hline
\end{tabular}

Table 9. Maloccusion \& Prolapse of Rectum

Animal No. Age at Death B. Wt. at Death

\begin{tabular}{|c|c|c|c|c|c|}
\hline \multirow{10}{*}{ 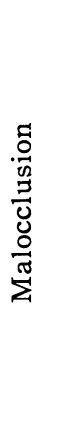 } & & & \multicolumn{2}{|c|}{ years months } & $\mathrm{g}$ \\
\hline & 우 & $\mathrm{T}-22$ & 6 & 0 & 350.5 \\
\hline & 우 & $\mathrm{T}-34$ & 5 & 8 & 445.5 \\
\hline & 우 & $\mathrm{V}-20$ & 4 & 9 & 261.0 \\
\hline & 우 & $A-42$ & 2 & 1 & 一 \\
\hline & 오 & $A-36$ & 2 & 10 & 326.0 \\
\hline & 오 & $C-10$ & $\cdot$ & 10 & 302.5 \\
\hline & $\hat{o}$ & White & \multicolumn{2}{|c|}{8 (about) } & 270.0 \\
\hline & 우 & $B-15$ & 2 & 0 & 289.5 \\
\hline & 오 & $A-56$ & 3 & 0 & 292.0 \\
\hline \multirow{4}{*}{  } & 오 & $\mathrm{K}$ 오 IV-01 & & 5 & 262.5 \\
\hline & 우 & $A-11$ & & 3 & 271.0 \\
\hline & & $\mathrm{V}-29$ & 3 & 7 & 417.0 \\
\hline & & $\mathrm{B}-20$ & 1 & 0 & 一 \\
\hline
\end{tabular}

る。不正咬合で死亡した動物の歯は Fig. 8,9 のように 歯の咬面が凹凸し不ぞろいであり，臼歯が外側にそり 返り，口内粘膜が圧迫され凹陷したり，歯肉が削られて いるものもある。切蔽はいずれも長く伸びている。また 上顎の切歯が伸びて内側に丸まり，下顎の切歯が上顎の 切歯の外側にあたるために上顎切歯のエナメル質が削ら れてしまっている動物（ㅇ-10）もみられる。歯牙の




$-56, \hat{\mathrm{O}} \mathrm{C}-24, \hat{\delta}$ シ口）も多い。本症は剖検しても歯以 外には特に異常が認められないので1974年までは死亡原 因不明に含めてあったが，不正咬合に気付いた1975年 3 月からは剖検時歯を検査することにしている。従って Table 8 で死亡原因不明と分類されている16匹のうち で1975年 3 月以前に死亡したものの中に不正咬合が含ま れている可能性があり, 剖検所見の臨床症状の記載から 推定して $2 \sim 6$ 匹は不正咬合による死亡であったと推察 されるので, 不正咬合の発現率は Table 8 の成績より 多いと考㝋られている。なお 1975 年 3 年以降の死亡48匹 中不正咬合は 9 匹18.8\%であった。Costello［2]によ れば 6 週令以上で死亡したチンチラの死亡原因の $25 \%$ 不正咬合と見積られている。不正咬合の家系的な関係を 調査することを試みたが，著者らのチンチラの飼育年数 が浅いので $3 〜 4$ 世代しかたどれないので十分に調査す ることができなかったが，不正咬合発生動物（生存して いる動物を含む） 14 匹中で令 S -59 の仔が 4 匹，曾孫 1 匹であり, 仔の内 2 匹は 里 $\mathrm{T}-46$ の仔であるので不正咬 合は遺伝的疾患と思われる。

なおチンチラの歯は切蔽が 1 対, 臼菌が 4 対で上顎, 下顎の合計 20 本である。且歯はいずれも歯槽内まで分岐 せず筒状であるので前臼歯と後臼歯を区別することが困 難である。哺乳類真獣下綱 Eutheria の歯式の基本型は $\mathrm{i} \frac{3}{3} \mathrm{c} \frac{1}{1} \mathrm{p} \frac{4}{4} \mathrm{~m} \frac{3}{3}=44$ と考えられているが，チ ンチラの所層するヤマアラシ亜目中でヤマアラシ（porcupine) の歯式は $\mathrm{i} \frac{1}{1} \mathrm{c} \frac{0}{0} \mathrm{p} \frac{1}{1} \mathrm{~m} \frac{3}{3}=20$ とさ れて扣り [10], チンチラの歯式についても Williams は $\mathrm{i} \frac{1}{1} \mathrm{c} \frac{0}{0} \mathrm{p} \frac{1}{1} \mathrm{~m} \frac{3}{3}$ と記載している[15]。著者 らがチンチラの初生仔について調べたところ，2 本の臼 歯がわずかに歯肉から顔を出す程度であり，これより小 型の 1 本が歯槽内に形成されており，さらに極めて小型 の 1 本が歯槽内に形成されているものが見られた。一方 生体では上顎の 4 本の臼歯がすべてほぼ同じ大きさであ るけれども，下顎の 1 本目の臼歯はやや小型である。

Table 8 に示した疾病の他にチンチラには毛を咬む ものがある。60日令以上の 雌動物 62 匹中毛を咬む動物 (Fur chewing) が16匹 (25.8\%), 雄動物 47 匹中 8 匹 $(17 \%)$, 雌雄合計して109匹中 $24 匹 （ 22 \%)$ 見られた。 防止法としては，犬，猫などの動物の毛を咬むのを防ぐ ために用いられるスプレー (CHEW STOP) を用いる とよい（粕谷次男私信）といらが，今後対策を検討する 必要がある。

\section{要 約}

Chinchilla lnaiger は南米 Andes 山脈原産の漓歯 目, ヤマアラシ亜目, チンチラ科, チンチラ属の毛皮獣 でモルモットと比較的近縁である。当研究室では1966年 チンチラの飼育繁殖を開始し, 常時120～150匹を飼育し, 実験動物化拈よび毛皮産業の発展を目標として研究を行 なってきている。本報は当研究室において最近 4 年間に 得られたチンチラの発育, 繁殖に間する成績をまとめた ものである。

初回腟開口日令は変異が大きく（71 日令以下～308 日 令), 45匹の平均は $173.2 \pm 57.6$ 日令であった。24匹 100 性同期の平均は $35.7 \pm 7.9$ 日であり, 15 62 日の範囲で あった。 5 匹の動物について調べられた 5 妊娠期間の平 均は 110.4日で 108 112日の範囲であった。3 年間に分 娭した 123 腹中で 5 月〜 8 月の分姺数が 81 腹 (65.9\%) で最も多い。従って妊娠期間約 110 日をさかのぼった 1 月〜 4 月すなわち春がチンチラの繁殖に最も適した季節 と考㝋られる。12月には分婏が見られず，妊娠期間をさ かのぼると 8 月〜 9 月上旬には受胎しない上らであり， Weir のいら summer anoestrus と考兄れる。産 仔数は $1 \sim 4$ 匹で 2 匹が最も多く $(46.3 \%)$, 平均 $1.90 \pm$ 0.76 匹 $(1 \sim 4)$ であった。出生時の性比は 133.7 (雌 98, 雄 131 匹）で, 他の動物に比較して雄が多いようで ある。1973 年の年間分娭数は 37 腹 71 匹で平均産仔数は 1.92 匹であった。離乳仔数は 59 匹，1腹平均 1.59 匹， 240 日令つまり成熟に達するとみなされる日令に達した もの50匹で 1 腹平均 1.35 であった。死因を調査した 91 匹 の動物の5ち, 事故死が 26 匹 (28.6\%), 乳仔の死亡が 23 匹 $(25.3 \%)$ と最も多かった。不正咬合が 9 匹 (9.9 $\%)$, 直腸脱が 5 匹 $(5.5 \%)$ と多いのが特徴的であった。

\section{謝辞}

チンチラの寄贈ならびに飼育指導を賜った黒住一井女 史，粕谷次男氏に感謝する。また飼育を援助していただ いた教室員各位に感謝する。な扮本研究は文部省科学研 究費特定研究「実験動物の純化と開発」に扩ける「実験 動物の繁殖維持の基礎：実験動物の繁殖に関する基礎的 研究」昭和50年度課題番号012209の援助を受けて行なわ れ，その要旨は第 11 回日本実験動物研究会 (1976.8. 26東京）において発表された。 


\section{文献}

[1] Bullard, R. W. (1953). The use of vaginal smears in a study of the estrus cycle of the female chinchilla. Anat. Rec. 117, 598.

[2] Costello, H. H. (1965). A primer on chinc hillas. Mod. Vet. Prac., 46, 194-198.

[3] 遠藤克, 西川滇八，相馬広明,佐久間勇次 (1972). Chinchilla の飼育について，実験動物. 21，184.

[4] Galton, M. (1968). Chinchilla sex ratio. J. Reprod. Fert., 211-216.

[5] Harry Eckard チンチラ飼育パンフレット

[6] 北海道立滝川音産試験場(1970).チンチラに関す る試験成績書，チンチラの飼育法と繁殖成績およ び毛皮生産について。

[7] Makino, S. (1950). Notes on the chromosomes of the porcupine and the chinchilla. Experientia, 9, 213-214.

[8] Medow, H. (1969). The chinchilla. The Tozer Co. Redwood City, California.

[9] Stockard, C. and Papanicolau, G. N. (1919). The vaginal closure membrane, copulation and the vaginal plug in the guinea-pig with further considerations of the oestrous rhythm. Biol. Bull. mar. bio. Lab., Woods, Hole 37, 222-245.

[10] 内田亨監修 (1966), 動物系統分類学, 10 (下) 脊 椎動物 (IV) 哺乳類。156-164, 中山書店。

[11] Weir, B. J. (1966). Aspects of reproduction in Chinchilla. J. Reprod. Fert. 12, 410-411.

[12] Weir, B. J. (1970). Chinchilla. In Reproduction and breeding techniqus for laboratory animals, 209-223. ed. Hafez. E. S. E. Philadelphia : Lea \& Febiger.

[13] Weir, B. J. (1972). The Chinchilla. In The UFAW handbook on the care and management of laboratory animals : 269-277. 4 th ed. Edinburgh : Churchill Livingstone.

[14] Weir, B. J. (1974). Reproductive characteristics of hystricomorph rodents. Symp. zool. Soc. Lond. 34, 265-301. In The Biology of Hystricomorph Rodents. Rowlands, I. W. and Weir, B. J., editors, Academic Press, London.

[15] Williams, C. S. F. (1976). Practical guide to laboratory animals. 3-11. The C. V. Mosby Company.

\section{Explanation of Figures}

Fig. 1. Adult female.

Fig. 2. View of chinchilla colony housed in polygamous breeding cages.

Fig. 3. Male puttng out his head from a hole of runner of a polygamous breeding cage, and note a metal collar (pointed by an arrow) on the female which pre- vents her to pass through the hole.

Fig. 4. Closed vagina of a female.

Fig. 5. Opened vagina of a female. C : Clitoris, A : Anus, V : Vagina.

Fig. 8. 9. Dentes of the adult. above : normal (3-year-old), below : malocclusion (2-year-old) 